\title{
The Influence of Career Development, Training, and Competence on Employee Performance at PT Angkasa Pura Logistic (APLog)
}

\author{
Fattahurafi Trisnawan ${ }^{1}$, Farida Elmi ${ }^{2}$ \\ \{rafitrisnawan@gmail.com ${ }^{1}$, farida.elmi@mercubuana.ac.id² \\ Universitas Mercubuana, Jakarta, Indonesia ${ }^{12}$
}

\begin{abstract}
Employee performance is one of the capitals for the company to achieve its goals, therefore employee performance should get attention from the company, because the decline in employee performance would have an impact to overall performance of the company, as it happened at PT. Angkasa Pura Logistic (APLog). The purpose of this research was to analyzed those influence from career development, training and competence on employee performance at PT. Angkasa Pura Logistic either simultaneously or partially. The population used in this research were all employee of PT. Angkasa Pura Logistic, amounted to 545 people. The sampling method used was simplified purposive sampling technique by assist of Slovin formula therefore it was obtained sample with total 90 respondents. Multiple linear regression used as analytical method with t-test and f-test obtained using SPSS ver 21.00. These results showed that there had an influence of career development, training and competence on employee performance at PT. Angkasa Pura Logistic either simultaneously or partially. This shows that the better competencies possessed by employee the more effective those training which held by company and the more precise career development that carried out by company, the more employee performance will be increase in carrying out their work.
\end{abstract}

Keywords: Career Development, Training, Competence, Employee Performance.

\section{Introduction}

\subsection{Background of Problem}

PT. Angkasa Pura Logistic (APLog) is a subsidiary of PT. Angkasa Pura I (Persero) which engaged in aviation services such as logistics, project logistics, cargo handling, regulated agents, warehousing and general sales agents. PT. Angkasa Pura Logistic strives to implement good corporate governance consistently and expresses it firmly in the 2014 Company Ethics Guidelines. The company strives to reach the highest level in the implementation of teamwork culture, work ethics and business ethics. Management calls for understanding and good cooperation from all parties in order to support proper, honest, legitimate and responsible practices in relation to company.

To achieve this goal, PT Angkasa Pura Logistic (APLog) should recognize to the performance of its employees, because employee performance is one of the assets for the company to achieve its goals, for that employee performance should get the attention from 
company, because decreased performance of employees could affect overall company performance, like it happened at PT. Angkasa Pura Logistic (APLog).

Based on these author's observations in the field related to employee performance, career development, training and competence at PT. Angkasa Pura Logistic (APLog) still below expectations. This shows that there still has employee who do not have the competence in completing the tasks which assigned by company also training and career development programs which not optimally implemented by PT. Angkasa Pura Logistic (APLog) so it has not been able to support employee performance.

Table 1. Competence Achievement, Career Development and Training Program include Employee Performance

\begin{tabular}{lllllllll}
\hline \multirow{2}{*}{ Year } & $\mathbf{E P}$ & \multicolumn{3}{c}{$\mathbf{C D}$} & & $\mathbf{T R}$ & \multicolumn{3}{c}{ CP } \\
\cline { 2 - 9 } & $\mathbf{R}$ & $\mathbf{T}$ & $\mathbf{R}$ & $\mathbf{T}$ & $\mathbf{R}$ & $\mathbf{T}$ & $\mathbf{R}$ & $\mathbf{T}$ \\
\hline 2015 & 3.62 & 4.20 & 3.50 & 4.11 & 3.56 & 4.35 & 3.69 & 4.26 \\
2016 & 3.43 & 4.23 & 3.32 & 4.20 & 3.39 & 4.33 & 3.55 & 4.31 \\
2017 & 3.42 & 4.25 & 3.20 & 4.22 & 3.41 & 4.29 & 3.52 & 4.31 \\
\hline Average & $\mathbf{3 . 4 4}$ & $\mathbf{4 . 2 4}$ & $\mathbf{3 . 2 8}$ & $\mathbf{4 . 2 0}$ & $\mathbf{3 . 4 2}$ & $\mathbf{4 . 3 2}$ & $\mathbf{3 . 5 5}$ & $\mathbf{4 . 3 1}$ \\
\hline
\end{tabular}

*Note: EP: employee performance, CD: career development, TR: Training, CP: competence, $R$ : realization, $T$ : target.

Source: Internal Data of APLog (2018)

To overcome these existing problems, PT Angkasa Pura Logistic (APLog) needs to provide training and career development programs as well as appropriate competencies to actualized employee performance that expected by company. The development and training programs as well as competencies which carried out by Human Capital Division should be based on company's vision to accomplish the company's goals optimally, so they could contribute to sustainable competitive advantage. Previous research has shown that career development could impact employee performance [1], company training also capable to increase employee performance [2] and the use of competencies within the company is very useful to lead human resources closer the targets that company wants to achieve [3].

Based on pre-survey which conducted to 31 respondents' employees of PT. Angkasa Pura Logistic (APLog) that related to career development as many as $41.9 \%$ disagreed with justice in providing equal opportunities to all employees to upgrade position or class, as many as $41.9 \%$ disagreed with promotions given by company based on objective and rational considerations, as well as $45.2 \%$ did not agree with this suitability of the position with employee wishes. Meaning career development which implemented by PT. Angkasa Pura Logistic (APLog) did not provided a picture of justice for their employee.

The pre-survey results related to training showed that as many as $6.5 \%$ stated that they did not agree with capability of trainer instructor to teach. Meaning that trainer instructor at PT. Angkasa Pura Logistic (APLog) lacks ability in provide knowledge to employees during the implementation of training at PT. Angkasa Pura Logistic (APLog). Besides that, 12.9\% stated that they did not agree with the books provided to supported these training activities. Meaning that there still has lack of book facilities to support these training activities at PT. Angkasa Pura Logistic (APLog). These pre-survey results that related to competence as many as $3.2 \%$ said that they did not agree with knowledge that employee had to complete the job well. This means that there is still employee who do not have the competence to complete the tasks assigned by the company. 
Based on these pre-surveys result related to employee performance, it was found that $16.1 \%$ disagreed with coming to the office on time, $6.5 \%$ disagreed with reliability in carrying out work procedures and as many as $6.5 \%$ disagreed with working in accordance to corridors of company's organizational structure. Based on this description, it means that employee performance of PT. Angkasa Pura Logistic (APLog) still has problems such as there still has employee who do not arrive on time, employees do not carry out work according to procedures and employees do not carry out work according to corridors of organizational structure.

The data descriptions shown above were encourage all data in clarifying these phenomena in the field, where these data were indicated that the employee performance of PT. Angkasa Pura Logistic (APLog) towards its work field tends to be low, which is shown by the data on the achievement of performance targets still lacked from the targets achieved therefore needs to be research depth comprehensively. The problem occurs in this research which is career development, training, and competence together impact the employee performance at PT. Angkasa Pura Logistic (APLog)?

\subsection{Literature Review}

\subsubsection{Career Development}

Career development is the personal changes that person do to achieve the career plan [4]. Meanwhile, Harun and Elmi explained that career development is a process which describes those efforts or activities from employee in choosing the goals and flow or flow of positions or jobs to achieve their respective career goals [5]. By increasing this career development and providing opportunities for employees to participate in existing career development programs at the company, it will increase the performance and productivity from employee themselves [6]. These dimensions which need to be considered in career development are fair treatment in career, concern for direct superiors, information about various promotion opportunities, interest to get promoted and level of satisfaction [4].

\subsubsection{Training}

Training is teaching or giving experience to someone to develop behavior (knowledge, skills, attitudes) in order to achieve something that they wanted [7]. Meanwhile, Mangkunegara revealed that training is a short-term educational process that used systematic and organized procedures, non-managerial employee learns technical knowledge and skills for limited purposes [8]. Training dimensions, including training objectives, materials, methods used, participant qualifications and instructor qualifications [8].

\subsubsection{Competence}

Competence is ability to carry out or perform the job or task based on skills and knowledge and supported by work attitude demanded by the job [9]. Thus, competence shows skills or knowledge characterized by professionalism in particular field as the most important thing, as an excellent in that field. These 3 dimensions of competence are ability, knowledge and work attitude [9].

\subsubsection{Employee Performance}

Employee performance is the result or overall success rate from person during a certain period in carrying out task compared to various possibilities, such as work standards, targets or goals or criteria which determined previously and mutually agreed by each party [10]. Performance appraisal is a system of periodic assessments towards employee performance 
which supports organizational success or related to implementation of their duties [7]. In Employee performance appraisal, work standards should be set up clearly to measured and understood. A job could be measured through 5 dimensions, which is quantity of work, quality of work, punctuality, reliability, and teamwork ability [10]. The theoretical framework from this research could be described as follows:

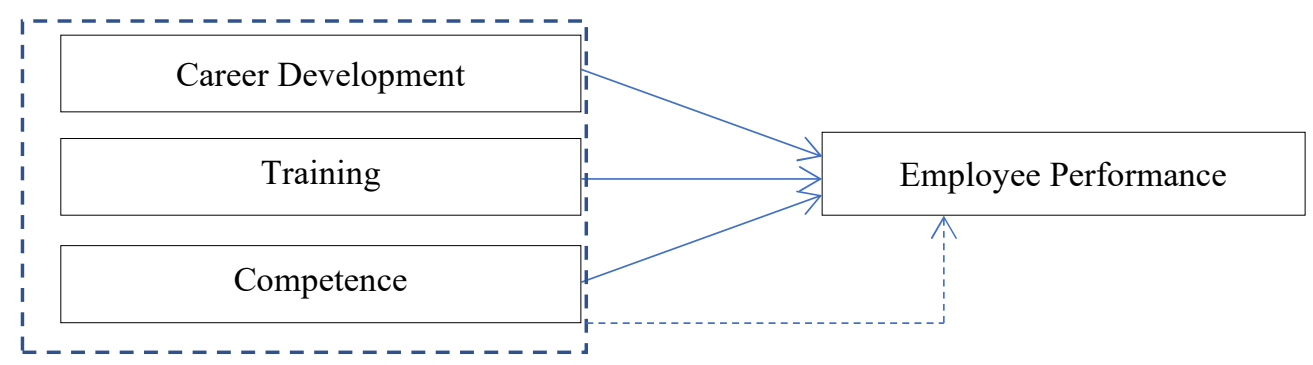

Fig 1. Theoretical Framework

Based on the phenomena which occur and theoretical framework and theories which been presented, the authors could formulate several hypotheses that will be examined in this research, such as: career development had impact on employee performance; training had impact on employee performance; competence had impact on employee performance; and career development, training and competence simultaneously impact on employee performance.

\section{Research Method}

This research type was included in quantitative research methods by explanatory research type. The quantitative research method is a method of problem solving which planned and careful, with a tightly structured design, systematically controlled data collection and were focused on the formulation of theories concluded inductively within the framework of empirically proving hypothesis [11]. Meanwhile, explanatory research is a research that explains the causal relationship between variables through hypothesis tests [12]. Data collection techniques used in this research were distributing and filling out questionnaires. The sampling technique used side purposive. The population in this research were all permanent employees of PT. Angkasa Pura Logistic (APLog), amounted to 545 people using the Slovin formula in order to obtain a sample of 90 respondents. Multiple linear regression analysis method with validity, reliability, t-test and F-test steps by SPSS ver 21.00.

\section{Results and Discussion}

\subsection{Results}

Based on characteristics from these 90 participants, it was seen that there were 52 male respondents $(68.9 \%)$ and 28 women (31.1\%). Through the data obtained, the majority of respondents were over the age of 25 and under 45 as many as 72 people (80.0\%). Furthermore, the majority of respondents' latest education was undergraduate 61 people 
(67.8\%) with length of work was between 1-5 years 43 people $(47.8 \%)$. Based on these calculations, it could be said that rcount value from all variable statements for career development, training, competence and employee performance were valid, because rcount> 0.300. Besides that, it could be described that each variable had Cronbach Alpha of 0.881, $0.917,0.931$ and 0.922 , all of them had value more than 0.60 , so the dimensions from all variables could be said reliable (consistent).

Based on these normality test from research data, it could be seen that the data points which spread around diagonal line and distribution from data points are unidirectional to diagonal line, meaning that data in this research fills the normality assumption criteria. According to heteroscedasticity test, it could be explained that these data was scattered around the number 0 ( 0 on the $\mathrm{Y}$ axis), and did not form a certain pattern or trend line, so it could be said heteroscedasticity and meet the requirements for regression analysis. Based on multicollinearity test, the Career Development variable was 0.633 , Training was 0.702 and Competency was 0.700 . Thus, the multiple regression line model used did not occur multicollinearity.

These Regression used to predictive purposed as well as for hypothesis test purposed. According to multiple linear regression analysis results it could be seen that:

a. Career development variable had $t$ value of 3,564 and its value was greater than t-table $(1,988)$. Meaning that career development had significant impact on employee performance at PT Angkasa Pura Logistic (APLog). This strengthens by sig value 0.001 $<0.05$.

b. Training variable had t-count value of 2.721 and its value was greater than t-table (1.988). This means that training had significant impact on the employee performance at PT Angkasa Pura Logistic (APLog). This strengthens by the sig value $0.008<0.05$.

c. Competence variable had t-count value of 7,174 and its value greater than t-table $(1,988)$. Meaning that competence had significant impact on employee performance at PT Angkasa Pura Logistic (APLog). This strengthens by sig value $0.000<0.05$.

d. F-count value was $60,732>$ F- table (3.103) with Sig 0.000 , due to the Sig. $0,000<$ Sig 0.05 , so it could be said that career development, training, and competence together (simultaneously) had significant impact on employee performance by $66.8 \%$ while the remaining $33.2 \%$ was influenced by other factors outside this research.

Coefficients

Table 2. Multiple Linear Regression Analysis

\begin{tabular}{|c|c|c|c|c|c|}
\hline \multirow[b]{2}{*}{ Model } & \multicolumn{2}{|c|}{$\begin{array}{l}\text { Unstandardized } \\
\text { Coefficients }\end{array}$} & \multirow{2}{*}{$\begin{array}{c}\text { Standardized } \\
\text { Coefficients } \\
\text { Beta }\end{array}$} & \multirow[b]{2}{*}{$\mathrm{t}$} & \multirow[b]{2}{*}{ Sig. } \\
\hline & $\mathrm{B}$ & Std. Error & & & \\
\hline (Constant) & 6.179 & 2.828 & & 2.185 & .032 \\
\hline Career Development & .260 & .073 & .274 & 3.564 & .001 \\
\hline Training & .147 & .054 & .198 & 2.721 & .008 \\
\hline Competence & .882 & .123 & .524 & 7.174 & .000 \\
\hline $\mathrm{F}$ & & & & 60.732 & .000 \\
\hline Adjusted $\mathrm{R}^{2}$ & & & .668 & & \\
\hline
\end{tabular}

Based on these test results, it could be described that almost all dimensions from career development, training, and competence variables had correlation with dimensions from employee performance variables. The highest correlation value is ability dimension from 
competency variable with teamwork ability dimension from employee performance variable with correlation value of 0.644 . While the lowest correlation value was dimension of participant qualification and teamwork ability which had correlation value of 0.209. However, there are several dimensions from career development which had no relationship (correlation) to dimensions from employee performance variables which is fair treatment in career with teamwork abilities, concern in employers with work quality, interest in promoted with teamwork abilities, level of satisfaction with the quantity of work and teamwork ability.

Besides that, several dimensions of training which have no relationship (correlation) to the dimensions from employee performance variables, such as training objectives with work quantity and punctuality, methods used with work quantity and punctuality, participant qualifications with punctuality and trainer qualifications with punctuality. Also the dimensions of participant qualifications with work quantity.

\subsection{Discussion}

Based on these analysis results from partial hypothesis test ( $t$ test), it is known that there had partially influence between career development towards employee performance at PT. Angkasa Pura Logistic (APLog). This shows that the better the career development, the better employee performance at PT. Angkasa Pura Logistic (APLog). Career development by means of fair treatment in a career, concern for superiors, availability of information on promotional opportunities so interest in being promoted and the level of satisfaction at work will improve employee performance which marked by good work performance, increased work discipline, punctuality, optimal attendance and good employee relations. These results strengthen the theory by Simamora which explained that individuals with positive career attitudes was indicated their commitment to the company by improving the performance and productivity [11]. The results of this research were also in line with prior research which show that career development had positive and significant impact on employee performance [1], [6].

Partially, there had significant influence between training on employee performance at PT. Angkasa Pura Logistic (APLog). This shown the better training conducted by PT. Angkasa Pura Logistic (APLog) will increase employee performance. The achievement of goals through job training will result in quantity of work, quality of work, punctuality, reliability and teamwork ability in performing tasks provided by the company will increase. This in line with theory which expressed by Simamora that stated that by provide the training, it will improve performance, update employees' skills in line with technological advances, reduce learning time for new employees so they would become components of work, help solve operational problems, prepare employee for promotions. Orientate employee towards organization and met personal needs [13]. These results were in line with prior research which indicated that training had positive and significant impact on employee performance [2], [5].

Partially, there had significant influence between competence on employee performance at PT. Angkasa Pura Logistic (APLog). This shows that the better the competence of employee, the better employee performance will be obtained at PT. Angkasa Pura Logistic (APLog), this related to the knowledge that employees have in using equipment, and knowledge in completing work according to qualifications which set by the company. Meaning that the ability to carry out or perform in work or task based on skills and knowledge and supported by work attitude demanded by the job will increase its performance. The results of this research were confirming Mc Clelland's theory which reveals that individuals who have competence will be able to produce innovative ideas, 
management skills, speed of learning networks, so they will be successful in predicting individual achievement in their work [14]. These results were in line with prior research that stated if competence had positive and significant impact on employee performance [3], [15].

According to the $\mathrm{F}$ test, it is found that together career development, training and competence had significant impact on employee performance at PT. Angkasa Pura Logistic (APLog). Meaning that career development, training and competence were also capable to increase employee reliability at work, because employee do work properly according to procedures, employee have ability to find solutions when experiencing deadlocks and employee will obey the rules and work procedures based on provision given by PT. Angkasa Pura Logistic (APLog). Besides that, by improving career development, training, and competence it will capable to increase teamwork ability, in this case employee who did work according to organizational structure, delegation of authority and tasks and employee who able to work well in a team according to provisions given by PT. Angkasa Pura Logistic (APLog). The results from this research were confirmed those researches which stated that career development, training and competence together (simultaneously) had significant positive impact on performance [16].

\section{Conclusions}

Based on these description and discussion from prior chapter, these following conclusions could be drawn such as: Partially, there had positive and significant influence from career development on employee performance. This shows that the more precise career development is, the employee's performance will increase. Partially, there had positive and significant impact from training on employee performance. This shows that the more effective the training that is conducted by the company will have an impact on improving employee performance. Partially, there had positive and significant influence from competence on employee performance.

This shows that the better the competence of the employee, the better the employee's performance. Simultaneously career development, training and competence had significant impact on employee performance. This shows that the better the competence of employees and the more effective the training which held by the company and the more appropriate career development that carried out by the company, the better the employee performance will be in carrying out on their work.

Referring to these conclusions above, these several suggestions that author could be drawn as follows: When conducted career development, companies were expected to provide a sense of fairness to their employees in their careers because this will have impact on teamwork and indirectly will have impact in improving performance. Besides that, Company is expected to have a sense of concern to work because this will have impact towards quality of work, or in the other hand the company should increase satisfaction in career development because this could bring increase to the quantity of work and teamwork ability. In order to improve company training, it is expected to have clear purposed of training because it would impact to quantity of work and punctuality of employees in completing work.

Furthermore, the methods used in this training were expected to be more focused on quantity of work and its punctuality and in terms of qualifications, the participants should give to employee who run out the times in completing their work therefore the quantity of work will increase. In order to improve employee competence, the company was expected to further improve their knowledge and ability to use the equipment provided by the company so these employees will capable to complete work in accordance to criteria which set by 
company. Moreover, the company needs to emphasize these compliances with rules and responsiveness act in accomplishing the work. For further researchers, it is hoped that they could adding more variables which relate to employee performance, such as work environment, organizational culture, communication systems, the way leader's work and bonuses and incentives. Also, it is hoped that this research will conduct in more than one company, therefore this result could be generalized to wider scope.

\section{References}

[1] Kudsi, M. R. (2017). Pengaruh pengembangan karir dan sistem insentif terhadap kinerja karyawan. Jurnal Manajemen, 9(2), 85-93).

[2] Triasmoko, D. (2014). Pengaruh Pelatihan Kerja Terhadap Kinerja Karyawan (Penelitian pada Karyawan PT Pos Indonesia (Persero) Cabang Kota Kediri). Jurnal Administrasi Bisnis, 12(1).

[3] Rande, D. (2016). Pengaruh Kompetensi Terhadap Kinerja Karyawan pada Dinas Perhubungan, Komunikasi Dan Informatika Kabupaten Mamuju Utara. Jurnal Katalogis, 4(2), 101-109.

[4] Siagian, S.P. (2012). Manajemen Sumber Daya Manusia. Jakarta: Bumi Aksara.

[5] Harun, E., \& Elmi, F. (2017). Pengaruh Training, Pengembangan Karier dan Insentif Terhadap Produktivitas Kerja Pegawai (Studi Kasus: DPPKAD di Pemprov Bangka-Belitung). Jurnal SWOT, VII(1), 89-105.

[6] Elmi, F., \& Ali, H. (2017). The Effect of Incentive, Training, and Career Development on Productivity of PT. Pelita Cengkareng Paper's Workers. International Journal of Applied Business and Economic Research, 15(6), 305-319.

[7] Elmi, F. (2018). Telisik Manajemen Sumber Daya Manusia. Jakarta: Mitra Wacana Media.

[8] Mangkunegara, A. P. (2013). Manajemen Sumber Daya Manusia, Cetakan kelima. PT. Remaja Rosdakarya. Bandung.

[9] Wibowo. (2016). Manajemen Kinerja. PT Raja Grafindo Persada. Bandung.

[10] Bangun, W. (2012). Manajemen Sumber Daya Manusia. Erlangga. Jakarta.

[11] Tanzeh, A. (2013). Pengantar Metode Penelitian. Yogyakarta: Teras.

[12] Hermawan, A. (2010). Penelitian Bisanis. Jakarta: PT. Grasindo.

[13] Simamora, H. (2014). Manajemen Sumber Daya Manusia. Jakarta: Gramedia.

[14] Usmara. (2012). Paradigma Baru Manajemen Sumber Daya Manusia, Jogjakarta: Asmara Books.

[15] Elmi, F., Triadhy, W., \& Aima, M. (2020). The Effect of Competence and Transformational Leadership Style on the Motivation and Its Implications on Teachers Performance at 01 and 02 North Petukangan Elementariy School. Dinasti International Journa of Education Management and Social Science, 1(3).

[16] Ataunur, I., \& Ariyanto, E. (2015). Pengaruh Kompetensi dan Pelatihan Terhadap Kinerja Karyawan PT Adaro Energy, Tbk. Telaah Bisnis, 16(2), 135-150. 